\title{
Current state of tumour necrosis factor $\alpha$ blockade in Wegener's granulomatosis
}

\section{Mukhtyar, R Luqmani}

Tumour necrosis factor $\alpha$ (TNF $\alpha$ ) is likely to be involved in the pathogenesis of Wegener's granulomatosis. This paper reviews published clinical trials of the anti-TNF $\alpha$ agents etanercept and infliximab with regard to their efficacy and safety in the treatment of Wegener's granulomatosis. On the basis of the high rate of adverse events, particularly an increased incidence of cancers, the use of etanercept in the management of Wegener's granulomatosis is not justified. However, the potential role for infliximab or the as yet untested adalimumab cannot be discounted. The development of novel approaches focusing on blockade of specific molecules including TNF $\alpha$ in the treatment of Wegener's granulomatosis is awaited.

$\mathrm{T}$ mour necrosis factor $\alpha(\mathrm{TNF} \alpha)$ has been successfully targeted in the management of adult inflammatory arthritides, especially rheumatoid arthritis, to produce remission of disease and improvement in radiological progression. ${ }^{1}$ Since its success in rheumatoid arthritis, anti$\mathrm{TNF} \alpha$ therapy has been used in other rheumatological conditions such as Behçet's disease, adult Still's disease, and juvenile idiopathic arthritis on a semi-empirical basis.

The treatment of Wegener's granulomatosis has vastly improved the high mortality of this disease since its original description in the 1930s, ${ }^{2}$ but induction of remission, relapses, and treatment related mortality remain a significant problem. The mortality of untreated Wegener's granulomatosis was $82 \%$ at one year, and the Fauci regimen of cyclophosphamide with prednisolone lowered the mortality to $12 \%$ at eight years. ${ }^{3}$ Prior to this Leib et al had demonstrated that treating systemic vasculitis (many cases were likely to have been either Wegener's granulomatosis or microscopic polyangiitis) with steroids increased median survival to $53 \%$ at five years. ${ }^{4}$ Cyclophosphamide induced morbidity, especially the risk of haemorrhagic cystitis and bladder cancer, ${ }^{5}{ }^{6}$ remained a significant concern in the maintenance of remission in Wegener's granulomatosis. The CYCAZAREM trial showed that there was no difference between cyclophosphamide and azathioprine in their ability to maintain remission in patients with antineutrophilic cytoplasmic antibody (ANCA) related systemic vasculitis, including a significant number with Wegener's granulomatosis. ${ }^{7}$ Although not ideal, this made azathioprine a more attractive option in the long term maintenance of remission in Wegener's granulomatosis as it has a favourable toxicity profile in comparison with cyclophosphamide, which still is currently the drug of choice to induce remission. The relapse rate is $50 \%$, despite good initial disease control in most patients. $^{8}$

The search for treatment options continues. In a recent trial of patients with non-renal Wegener's granulomatosis, methotrexate was found to be a safer and equally effective at inducing remission, but relapse following discontinuation of therapy was common. ${ }^{9}$ Anti-TNF $\alpha$ therapy has been considered for use in patients with Wegener's granulomatosis, and since 2001 there have been five small open labelled trials and one large randomised controlled trial presented in English language journals that have looked at the role of anti-TNF $\alpha$ therapy in the management of systemic vasculitis. Here, we review the potential mechanisms for anti-TNF therapy, and discuss the results of current trials.

\section{THE ROLE OF TNF $\alpha$ IN WEGENER'S GRANULOMATOSIS}

In a recent murine model of proteinase-3 (PR3) ANCA induced vasculitis, TNF $\alpha$ was required to produce an inflammatory response. ${ }^{10}$ Local panniculitis was produced in wild-type mice on passive transfer of murine PR3 ANCA but only if mice received intradermal TNF $\alpha$. This suggests that both ANCA and TNF $\alpha$ are necessary in the production of an inflammatory response. Similar experiments demonstrate the requirement for a proinflammatory stimulus in myeloperoxidase (MPO) ANCA induced vasculitis in Brown Norway rats. ${ }^{11}$ However, MPO ANCA can act independently of TNF $\alpha$ in a mouse model of microscopic polyangiitis. ${ }^{12}$

Deguchi $e t \mathrm{al}^{13}$ showed that TNF $\alpha$ mRNA was upregulated in peripheral mononuclear cells from patients with Wegener's granulomatosis compared with healthy controls. The mechanisms of this enhanced expression are not entirely clear but Lùdvíksson et $a^{14}$ demonstrated that monocytes in patients with Wegener's granulomatosis secrete increased amounts of interleukin (IL)-12. IL-12 skews the inflammatory process in favour of a T helper (Th) 1 cytokine response by inducing the production of interferon $\gamma$ and, to a lesser extent, TNF $\alpha$ from natural killer cells and $\mathrm{T}$ cells, and promoting the development and differentiation of Th 1 cells. $^{15}$

Neutrophils can be induced to express surface PR3 by TNF $\alpha$ and IL-8 in vitro and in vivo. This translocation of the normally intracytoplasmic antigen PR3 to the cell membrane makes it available for binding with ANCA. ${ }^{16}$ TNF $\alpha$ primed mononuclear cells from healthy donors can synthesise PR3 de novo. ${ }^{17}$ Once bound, the antigen-antibody complex leads to neutrophil degranulation and production of reactive oxygen species. The exact signalling leading to the respiratory burst is unknown but it probably involves the phosphorylation of the tyrosine kinase Syk (a non-receptor protein tyrosine kinase responsible for signal transduction in neutrophils and macrophages), as shown by Hewins et $a l^{18}$ in TNF $\alpha$ primed neutrophils.

PR3 proteins translocate to the surface of neutrophils during apoptosis and are subsequently opsonised by ANCA. ${ }^{19}$

Abbreviations: ANCA, antineutrophilic cytoplasmic antibody; BVAS, Birmingham Vasculitis Activity Score; IL, interleukin; MPO,

myeloperoxidase; PR3, proteinase-3; Th, T helper; TNF, tumour necrosis factor; WGET, Wegener's Granulomatosis Etanercept Trial 
Opsonised cells have a higher rate of uptake by the clearing macrophages. Usually, clearance of apoptotic material is anti inflammatory; however, ANCA opsonised cells are capable of upregulating $\mathrm{TNF} \alpha$ and inducing thromboxane $\mathrm{B}_{2}$ production by the macrophages that have engulfed them. ${ }^{20}$ This will lead on to further priming of neutrophils, and a self-perpetuating proinflammatory cycle. TNF $\alpha$ production in situ is sustained in extravascular sites once inflammation has been initiated. ${ }^{21}$ In kidney biopsies from patients with Wegener's granulomatosis, mRNA expression of TNF $\alpha$ and IL- $1 \beta$ is increased in the infiltrating mononuclear cells in the perivascular and periglomerular areas.

Granulomas in Wegener's granulomatosis consist of CD4+ $\mathrm{T}$ cells (a significant proportion of which lack CD28), monocyte derived tissue macrophages, giant cells, and neutrophils surrounding a necrotic area. The CD4+CD28- T cells secrete large amounts of Th 1 cytokines including TNF $\alpha$, in a fashion similar to the excess Th 1 cytokine secretion seen in vasculitic lesions. ${ }^{22}$ There is considerable circumstantial evidence for the involvement of TNF $\alpha$ at all stages of our current understanding of the pathogenesis of Wegener's granulomatosis. Although there is no direct evidence for $\mathrm{TNF} \alpha$ pathogenicity, the presence of such a potent cytokine at sites of inflammation in vasculitis suggests that it is unlikely to be an innocent bystander.

\section{EVIDENCE FOR THE EFFECTIVENESS OF TNF $\alpha$ BLOCKADE IN WEGENER'S GRANULOMATOSIS Methods}

Using the search string ("tumour necrosis factor-alpha/ antagonists and inhibitors" [MeSH] OR "infliximab" [substance name] OR "TNFR-Fc fusion protein" [substance name]) AND "Wegener's granulomatosis" [MeSH] on Medline and limiting the results to English language, we identified six trials of anti-TNF therapy in systemic vasculitis

Table 1 A comparison of patient profiles in two etanercept trials in Wegener's granulomatosis (WG) ${ }^{23} 26$

\begin{tabular}{|c|c|c|c|}
\hline Trial & Drug & $\begin{array}{l}\text { No (\%) of patients } \\
\text { with a diagnosis } \\
\text { of new WG }\end{array}$ & $\begin{array}{l}\text { Mean BVAS- } \\
\text { WG at } \\
\text { recruitment }\end{array}$ \\
\hline Stone et al, 2001 & Etanercept & 0 & 3.6 \\
\hline $\begin{array}{l}\text { Wegener's } \\
\text { Granulomatosis } \\
\text { Etanercept Trial, } \\
2005\end{array}$ & $\begin{array}{l}\text { Etanercept } \\
\text { Placebo }\end{array}$ & $\begin{array}{l}31(34) \\
49(45)\end{array}$ & $\begin{array}{l}6.5 \\
7.5\end{array}$ \\
\hline
\end{tabular}

BVAS-WG, Birmingham Vasculitis Activity Score for Wegener's Granulomatosis. including Wegener's granulomatosis. We present an analysis of the available data.

\section{Etanercept}

Two trials have assessed the role of etanercept in the management of Wegener's granulomatosis. Stone et $a^{23}$ tested anti-TNF $\alpha$ therapy for the first time in the management of Wegener's granulomatosis. Etanercept was assessed in an open pilot in a dose of $25 \mathrm{mg}$ twice weekly for six months in 20 patients with Wegener's granulomatosis, most of whom $(70 \%)$ had never had a disease remission. It was added to the standard treatment for Wegener's granulomatosis. The primary objective was to assess the safety of combining etanercept with the standard treatment of Wegener's granulomatosis. The combination of etanercept with either cyclophosphamide or methotrexate in Wegener's granulomatosis was no more toxic than what was expected from trials of etanercept in rheumatoid arthritis. Adverse events occurred in 25\% patients, none of which were classified as severe. Within the treatment period, $80 \%$ of the patients achieved remission and the mean Birmingham Vasculitis Activity Score for Wegener's Granulomatosis $(\text { BVAS-WG })^{24} 25$ fell from a mean of 3.6 at recruitment to 0.6 at six months $(\mathrm{p}<0.001)$. However, three patients developed major (organ or life threatening) flares despite etanercept therapy.

The Wegener's Granulomatosis Etanercept Trial (WGET) ${ }^{26}$ tested etanercept in a randomised placebo controlled trial. Etanercept or placebo was added to standard therapy and patients were followed up for a minimum of 12 months. The patient profile differed from the previous etanercept study ${ }^{23}$ (table 1). The patients in WGET had more active disease compared with the earlier pilot study; the BVAS-WG at trial entry was higher (table 1), and a higher proportion of the patients had new onset Wegener's granulomatosis.

A total of 89 patients were randomised to the etanercept arm and 91 to the placebo arm. The mean treatment period for the etanercept group was 25 months and that for the control group was 19 months. There was no difference in the two arms in the ability to induce remissions or prevent further disease flares. Furthermore, there was no difference in the number of withdrawals from therapy and adverse effects including deaths (table 2). There number of adverse events was large in both groups, and over half of all patients treated with standard therapy had a serious adverse event over the mean follow up period of 27 months.

\section{Risk of cancer}

Apart from the failure of $\mathrm{TNF} \alpha$ blockade to alter disease activity above and beyond the effects of standard immunosuppression and the sobering number of adverse events, the most worrying feature was the incidence of cancers in the

Table 2 Remissions, flares, withdrawals, and adverse events in two trials of etanercept in Wegener's granulomatosis*

\begin{tabular}{|c|c|c|c|c|}
\hline & \multirow{2}{*}{$\begin{array}{l}\text { Stone et } a P^{3} \\
\text { Etanercept } \\
(n=20)\end{array}$} & \multicolumn{3}{|c|}{ Wegener's Granulomatosis Etanercept Trial ${ }^{26}$} \\
\hline & & $\begin{array}{l}\text { Placebo } \\
(n=91)\end{array}$ & $\begin{array}{l}\text { Etanercept } \\
(\mathrm{n}=89)\end{array}$ & p value $†$ \\
\hline \multirow{5}{*}{$\begin{array}{l}\text { Total remissions achieved } \\
\text { Sustained remission (for } 6 \text { months) } \\
\text { No of severe flares (organ or life } \\
\text { threatening events) } \\
\text { Withdrawals } \\
\text { Severe adverse events }\end{array}$} & $16(80)$ & $84(92)$ & $80(90)$ & 0.35 \\
\hline & NA & 64 (75) & $62(70)$ & 0.39 \\
\hline & 3 & 20 & 27 & 0.87 \\
\hline & $1(5)$ & $34(36)$ & 35 (39) & ND \\
\hline & $0(0)$ & (57) & (56) & 0.9 \\
\hline
\end{tabular}

*Values outside parentheses represent the number of patients or the number of events in the case of flares and values in parentheses represent percentages.

tp values calculated compare the two arms of the Wegener's Granulomatosis Etanercept Trial.

NA, not applicable; ND, no data available. 


\begin{tabular}{ll}
$\begin{array}{l}\text { Table } 3 \text { Risk of malignancies in patients with } \\
\text { Wegener's granulomatosis }\end{array}$ \\
\hline \multicolumn{1}{l}{ Standardised incidence ratio } \\
Cancer & $(95 \% \mathrm{Cl})$ \\
\hline Bladder cancer & $4.8(2.6$ to 8.1$)$ \\
Squamous cell carcinoma & $7.3(4.4$ to 12$)$ \\
Leukemias & $5.7(2.3$ to 12$)$ \\
Lymphomas & $4.2(4.2$ to 8.3$)$ \\
\hline
\end{tabular}

patients in the etanercept treated group $(p=0.01)$. Six of 92 patients developed a solid tumour (two mucinous adenocarcinoma of the colon, one metastatic cholangiocarcinoma, one renal cell carcinoma, one breast carcinoma, and one recurrence of liposarcoma 10 years after its original excision). During the six month follow up period after treatment, three additional solid cancers were identified-one in the etanercept group (prostatic adenocarcinoma) and two in the placebo group (cholangiocarcinoma and metastatic renal cell carcinoma). The latter occurred in a patient who had discontinued treatment and was being treated with infliximab at time of diagnosis. Seven skin cancers were identified: three in the etanercept arm and four in the placebo arm. The difference between the two groups was not significant.

Wegener's granulomatosis itself is associated with an increased risk of malignancy. Tatsis et $a l^{27}$ calculated the odds ratio of malignancy in Wegener's granulomatosis at 1.79 $(\mathrm{p}=0.0876 ; 95 \%$ confidence interval (CI) 0.92 to 3.48$)$. The odds ratio of developing a renal cell carcinoma was calculated as $8.73(\mathrm{p}=0.0464,95 \%$ CI 1.04 to 73.69$)$. Knight et al ${ }^{28}$ linked the Swedish inpatient register and the Swedish cancer register and followed the cohort of patients with Wegener's granulomatosis for 26 years. They found a twofold overall risk of cancer in Wegener's granulomatosis. The standardised incidence ratio for specific malignancies was as given in table 3. A UK based study of incidence of malignancy in Wegener's granulomatosis calculated the relative risk of a cancer at 6.02 (95\% CI 3.72 to 9.74) compared with age matched healthy controls. ${ }^{29}$

All the patients in the WGET trial were also on cyclophosphamide, which is known to increase the risk of bladder ${ }^{5} 6$ and haematological cancers. However, the malignancies observed here were different and both arms of the trial were equal in their exposure to cyclophosphamide. The control arm had more newly diagnosed patients $(p=0.01)$ but the mean duration of disease was not different between the two arms. This would mean that the only variable of significance was etanercept. To date, there is no evidence linking etanercept to an increased risk of cancer, but there is recent evidence that TNF $\alpha$ promotes invasiveness of cholangiocarcinoma via the p75 receptor. ${ }^{30}$ Wolfe et al ${ }^{31}$ prospectively studied 18572 patients with rheumatoid arthritis from the National Data Bank for Rheumatic Diseases, Wichita, USA and found that although the standardised incidence ratio for lymphomas was higher in the patients on biological therapies, there was insufficient evidence to conclusively prove the association.

\section{Infliximab}

We found four clinical trials of infliximab ${ }^{32-35}$ in systemic vasculitis including Wegener's granulomatosis. From the four trials, there were 35 patients with Wegener's granulomatosis among a total cohort of 54 patients treated with infliximab. One trial $^{34}$ studied Wegener's granulomatosis exclusively. The other trials, unfortunately did not stratify their results according to the underlying diagnosis. Therefore, the statistics presented below also include microscopic

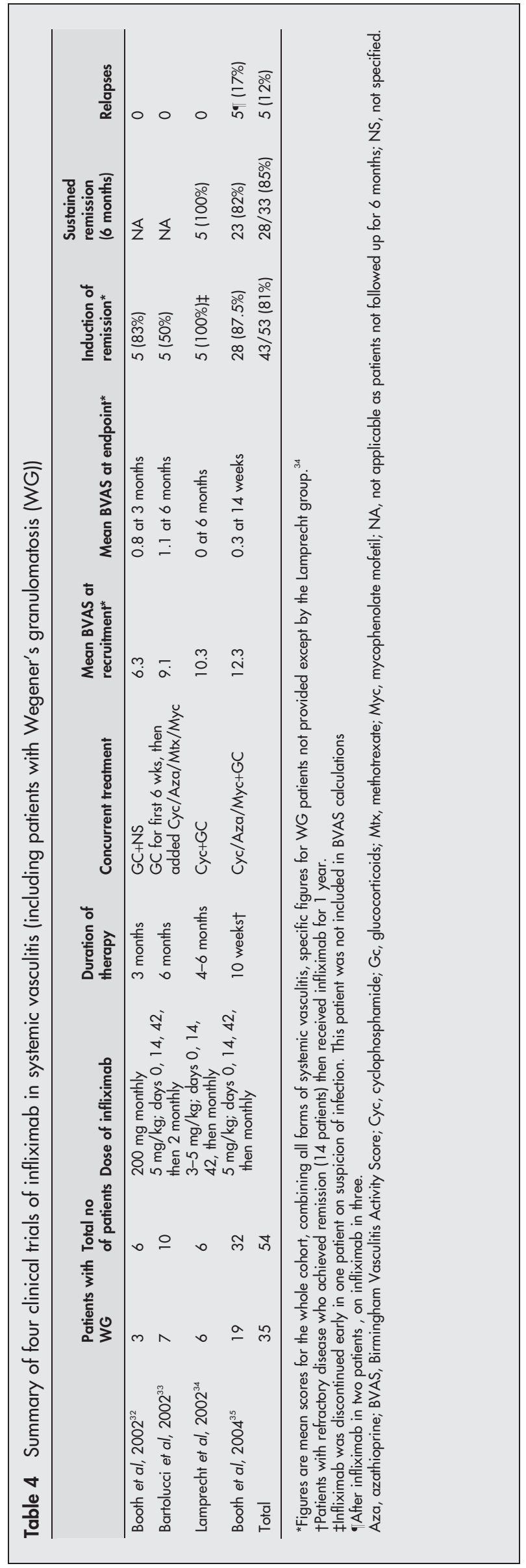


Table 5 Number of adverse events in four clinical trials of infliximab in systemic vasculitis (including patients with Wegener's granulomatosis (WG))

\begin{tabular}{llll}
\hline & $\begin{array}{l}\text { Severe adverse } \\
\text { events }\end{array}$ & Infections & Deaths \\
\hline Booth et al, 2002 $20002^{33}$ & 0 & 0 & 0 \\
Bartolucci et al, 2002 & 0 & 0 & 0 \\
Lamprecht et al, 2002 & 0 & 0 & 0 \\
Booth et al, 2004 $4^{35}$ & 10 & 6 & $2^{*}$ \\
Total & 10 (19\%) & $6(11 \%)$ & $2(4 \%)$ \\
\hline *One death was eight weeks after stopping infliximab. & \\
\hline
\end{tabular}

polyangiitis ( 16 patients), rheumatoid vasculitis ( 2 patients), and mixed cryoglobulinaemia (l patient).

All patients were treated with doses between $3 \mathrm{mg} / \mathrm{kg}$ and $5 \mathrm{mg} / \mathrm{kg}$ of infliximab at a frequency of one to two monthly infusions. Except for Bartolucci et al, ${ }^{33}$ all the trials continued standard therapy for systemic vasculitis. The Bartolucci group stopped all immunosuppressants (apart from glucocorticoids) on commencing infliximab, ${ }^{33}$ and then the immunosuppressants were reintroduced after six weeks. The methodology of the four studies is described in table 4 .

The cohort of patients selected for the studies was mixed including new cases, flares, and persistent disease as reflected by the mean BVAS from 6.3 to 12.3 . Booth $e t a^{35}$ stratified the study into two groups-new patients or flares with a mean BVAS of 17.1, and persistent disease with a mean BVAS of 10.3. The patients in the latter arm who benefited from infliximab continued on it for a total duration of one year. All others including all patients in the new/flare arm received infliximab for only 10 weeks. The other trials administered infliximab for between three and six months.

Two trials (Lamprecht et $a l^{34}$ and Booth et al $(2004)^{35}$ ) continued following the patients beyond the use of infliximab to monitor the maintenance of remission. The reduction of mean BVAS was significant and clinically meaningful. The improvements were evident at six weeks. Bartolucci et al $l^{33}$ reported the BVAS to be 1.9 at six weeks and Booth et $a l^{35}$ reported the mean time to remission as 6.4 weeks. Although the numbers are small, and the trials studied systemic vasculitis rather than Wegener's granulomatosis, 43 of the 53 patients $(81 \%)$ given infliximab experienced induction of remission. The figure of $81 \%$ becomes impressive when considered in the light of the fact that 37 of these 53 patients (69\%) had failed to achieve a remission on standard treatment and had been classified as "refractory". Of the 43 patients who had remission induction, 33 were followed for at least a year. Of these, $28(85 \%)$ achieved sustained remission, defined as BVAS of 0 for at least six months. Of the 10 patients who did not achieve a remission, BVAS data are available on six. All six had improvement in their BVAS scores. Of the four for whom data are not available, one died and the other three benefited with CAMPATH- $1 \mathrm{H}$, rituximab, and leflunomide, respectively.

There were five relapses in the 43 patients who were reported to achieve remission. A further two patients in the Bartolucci group had worsening of their BVAS while still on infliximab. ${ }^{33}$ They did not achieve remission. The numbers here are difficult to interpret because of the variable length of treatment and follow up. Nevertheless, this would mean the relapse rate was at least $12 \%$ ( 5 relapses from 43 remissions).

On the issue of safety, table 5 provides data on adverse events including infections and deaths. There were six episodes of confirmed infection while on infliximab (table 6) and two suspected illnesses attributed to septic causes. The data on withdrawals from the Booth et al ${ }^{35}$ trial are unclear. Lamprecht et al ${ }^{34}$ withdrew one patient due to a
Table 6 Occurrence of infections in four clinical trials of infliximab ${ }^{32-35}$ in systemic vasculitis (including patients with Wegener's granulomatosis (WG))

\begin{tabular}{|c|c|c|}
\hline Infection & Organism & Comment \\
\hline Bronchopneumonia* & $\begin{array}{l}\text { Haemophilus } \\
\text { influenzae }\end{array}$ & $\begin{array}{l}\text { Bronchiectasis requiring } \\
\text { hospitalisation }\end{array}$ \\
\hline Urinary sepsis & Klebsiella & $\begin{array}{l}\text { Requiring hospitalisation; } \\
\text { creatinine } 425 \mu \mathrm{mol} / / \mathrm{l}\end{array}$ \\
\hline Leg abscess & $\begin{array}{l}\text { Methicillin resistant } \\
\text { Staphylococcus } \\
\text { aureus }\end{array}$ & $\begin{array}{l}\text { Surgical drainage } \\
\text { required }\end{array}$ \\
\hline Endophthalmitis & Nocardia & Evisceration required \\
\hline $\begin{array}{l}\text { Skin ulcer } \\
\text { Urinary tract infection }\end{array}$ & $\begin{array}{l}\text { Staphylococcus } \\
\text { aureus } \\
\text { Escherichia coli }\end{array}$ & Same patient \\
\hline
\end{tabular}

*The same patient had a similar episode 20 weeks after coming off infliximab. The skin ulcer and urinary tract infection occurred in the same individual.

suspected infection that remained unproved. Bartolucci et $a l^{33}$ and Booth et al (2002) $)^{32}$ did not report any withdrawals.

There were two deaths-one while on infliximab (from pulmonary haemorrhage) and one at eight weeks follow up after completing infliximab (from bronchopneumonia). Both the patients had MPO-ANCA related renal vasculitis rather than Wegener's granulomatosis. No organisms were isolated in either of the two cases.

\section{The differences between infliximab and etanercept}

Infliximab has previously been successful in managing granulomatous disorders such as Crohn's disease when etanercept has failed. There are some fundamental differences between etanercept and infliximab. ${ }^{36}$

Etanercept is a complex of two p75 TNF $\alpha$ receptors coupled to the Fc portion of a monoclonal human antibody. It forms a one to one bond with the active trimeric TNF $\alpha$ molecule, leaving one potential binding site free. The bonds are relatively unstable with the potential to dissociate in the presence of competitors for the TNF $\alpha$ molecules, namely the cell surface p55 and p75 receptors. The effects of etanercept may be transient. In the presence of more molecules of etanercept, the dissociated molecules can re-associate with surrounding available etanercept. However, in areas of poor vascularity, for example granulomas, etanercept may not achieve adequate levels to mop up the dissociated TNF $\alpha$ molecules. It would be logical to hypothesise that these dissociated TNF $\alpha$ molecules could be free to bind with cellular receptors and upregulate the inflammatory processes.

Infliximab is a chimeric (part mouse, part human) monoclonal antibody. It can bind up to two TNF $\alpha$ molecules and up to three molecules of infliximab can bind to one TNF $\alpha$ molecule thus satisfying all the binding sites on the TNF $\alpha$ molecule. It binds with monomeric molecules as well and therefore may prevent the formation of the active trimeric form. It forms more stable complexes with soluble TNF $\alpha$ molecules compared with etanercept. Besides its actions on the soluble molecules of $\mathrm{TNF} \alpha$, infliximab demonstrates actions against cell bound forms of TNF $\alpha$. It can lyse cells which express surface TNF by way of complement fixation, and it also exhibits a superior affinity compared with etanercept in the ability to bind with transmembrane forms of $\mathrm{TNF} \alpha{ }^{36}$

Perhaps there are fundamental differences between etanercept and infliximab in terms of tissue penetration, the size of the therapeutic effect in blocking TNF at low level with etanercept, compared to intermittent pulses as is the case with infliximab. There is as yet no published work on the potential clinical implications of these differences. 


\section{EVIDENCE FOR THE INDUCTION OF VASCULITIS BY TNF $\alpha$ BLOCKADE}

Anti-TNF $\alpha$ therapy has been associated with production of antibodies including antinuclear antibody and anti-DsDNA antibody. ${ }^{37}{ }^{38}$ This is well documented with infliximab, but there are reports of antibody production with the use of etanercept as well. ${ }^{39}{ }^{40}$ A small proportion of patients who develop these antibodies develop a lupus-like illness-sometimes with the production of antihistone antibodies as well. $^{41}{ }^{42}$ There are also reports of patients developing vasculitis attributable to these therapies, with generation of atypical ANCAs. ${ }^{43}{ }^{44}$ The vasculitis is cutaneous in the vast majority of patients but glomerulonephritis has also been reported. ${ }^{45}{ }^{46}$ The vasculitis seems to be reversible, and it has been reported with etanercept as well as infliximab, sometimes in the same patient. ${ }^{43}$ There are not enough data to suggest that the phenomenon occurs more frequently with one or the other agent, but it has been reported more often in patients on infliximab. There is no obvious explanation for this phenomenon, but likely hypotheses include one or more of the following:

- Wiping out TNF $\alpha$ could potentially skew the inflammatory process from a Th 1 led response to a Th 2-like (lupus-like) response. The inhibition of TNF $\alpha$ does inhibit cytotoxic T cell responses, promoting humoral immunity in murine models. $^{47}$

- Infliximab induces apoptosis and reduced levels of Creactive protein may be responsible for a delay in the clearance of apoptotic debris. This may result in the exposure of intracellular material invoking an antibody response. ${ }^{48}$

- Increased levels of soluble TNF receptors have been identified in acute rheumatic conditions including systemic lupus erythematosus and ANCA associated vasculitis. ${ }^{49} 50$ Whether this is of consequence or simply an epiphenomenon remains to be identified. In the event of soluble TNF receptors being pathogenic, addition of etanercept may not be helpful.

These explanations are speculative at best. Their causality needs to be evaluated.

\section{CONCLUSIONS}

TNF $\alpha$ still remains a potential target in the management of Wegener's granulomatosis and other ANCA associated vasculitis. The use of etanercept cannot be justified after the results of the WGET trial. However, that is no reason to discount the potential role for infliximab or the as yet untested adalimumab. The small trials discussed above have shown that sustained remission is a possibility in patients with refractory disease. These results certainly merit a controlled trial of one or both monoclonal antibodies in the treatment of ANCA associated systemic vasculitides including Wegener's granulomatosis. The pharmacology of etanercept may explain to a certain extent the reasons for its failure, but part of the problem may also be our limited understanding of the pathophysiology of the disease. It has been suggested that granulomatosis and vasculitis may have different pathogenetic mechanisms, or may represent different ends of the spectrum of Wegener's granulomatosis and therefore should be treated differently. ${ }^{51}{ }^{52}$ Understandably, the emphasis has been on treating the vasculitic component of these diseases since this carries the higher mortality. Granulomatosis represents the chronic aspect of the disease and theoretically, blockade of TNF $\alpha$ should have a place here.

We await novel approaches concentrating on specific blockade of $\mathrm{TNF} \alpha$ and other key molecules in the vasculitic and granulomatous process in the effort to find effective and safe regimens for long term control of Wegener's granulomatosis.

\section{Authors' affiliations}

C Mukhtyar, Stoke Mandeville Hospital, Aylesbury, UK

R Luqmani, Nuffield Orthopaedic Centre and University of Oxford, Oxford, UK

Competing interests: none declared

Correspondence to: Dr R Luqmani, Rheumatology Department, Nuffield Orthopaedic Centre, Windmill Road, Oxford OX3 7LD, UK; raashid. luqmani@noc.anglox.nhs.uk

\section{REFERENCES}

1 Lipsky PE, van der Heijde DM, St Clair EW, Furst DE, Breedveld FC, Kalden JR, et al. Anti-Tumor Necrosis Factor Trial in Rheumatoid Arthritis with Concomitant Therapy Study Group. Infliximab and methotrexate in the treatment of rheumatoid arthritis. Anti-Tumor Necrosis Factor Trial in Rheumatoid Arthritis with Concomitant Therapy Study Group. N Engl J Med 2000;343: 1594-602.

2 Wegener F. On generalised septic vessel diseases. By Friedrich Wegener, 1937 [translation]. Thorax 1987;42:918-19.

3 Fauci AS, Haynes BF, Katz P, Wolff SM. Wegener's granulomatosis: prospective clinical and therapeutic experience with 85 patients for 21 years. Ann Intern Med 1983;98:76-85.

4 Leib ES, Restivo C, Paulus HE. Immunosuppressive and corticosteroid therapy of polyarteritis nodosa. Am J Med 1979;67:941-7.

5 Stillwell TJ, Benson RC Jr, DeRemee RA, McDonald TJ, Weiland LH. Cyclophosphamide-induced bladder toxicity in Wegener's granulomatosis. Arthritis Rheum 1988;31:465-70.

6 Talar-Williams C, Hijazi YM, Walther MM, Linehan WM, Hallahan CW, Lubensky I, et al. Cyclophosphamide-induced cystitis and bladder cancer in patients with Wegener granulomatosis. Ann Intern Med 1996;124:477-84.

7 Jayne D, Rasmussen N, Andrassy K, Bacon P, Tervaert JW, Dadoniene J, et al; European Vasculitis Study Group. A randomized trial of maintenance therapy for vasculitis associated with antineutrophil cytoplasmic autoantibodies. N Engl J Med 2003;349:36-44.

8 Gordon M, Luqmani RA, Adu D, Greaves I, Richards N, Michael J, et al. Relapses in patients with a systemic vasculitis. Q J Med 1993;86:779-89.

9 de Groot K, Rasmussen N, Bacon PA, Cohen Tervaert JW, Feighery C, Gregorini G, et al. Randomized trial of cyclophosphamide versus methotrexate for induction of remissions in "non-renal" ANCA-associated vasculitis. Arthritis Rheum 2005 (in press).

10 Pfister H, Ollert M, Frohlich LF, Quintanilla-Martinez L, Colby TV, Specks U, et al. Antineutrophil cytoplasmic autoantibodies against the murine homolog of proteinase 3 (Wegener autoantigen) are pathogenic in vivo. Blood 2004;104:1411-18.

11 Heeringa P, Foucher P, Klok PA, Huitema MG, Tervaert JW, Weening JJ, et al. Systemic injection of products of activated neutrophils and $\mathrm{H}_{2} \mathrm{O}_{2}$ in myeloperoxidase-immunized rats leads to necrotizing vasculitis in the lungs and gut. Am J Pathol 1997;151:131-40.

12 Xiao H, Heeringa $P, H u P$, et al. Antineutrophil cytoplasmic autoantibodies specific for myeloperoxidase cause glomerulonephritis and vasculitis in mice. J Clin Invest 2002;110:955-63.

13 Deguchi Y, Shibata N, Kishimoto S. Enhanced expression of the tumour necrosis factor/cachectin gene in peripheral blood mononuclear cells from patients with systemic vasculitis. Clin Exp Immunol 1990;81:311-14.

14 Lùdvíksson BR, Sneller MC, Chua KS, Talar-Williams C, Langford CA, Ehrhardt RO, et al. Active Wegener's granulomatosis is associated with HLA$\mathrm{DR}+\mathrm{CD} 4+\mathrm{T}$ cells exhibiting an unbalanced Th1-type T cell cytokine pattern: reversal with IL-10. J Immunol 1998;160:3602-9.

15 Trinchieri G. Interleukin-12: a cytokine produced by antigen-presenting cells with immunoregulatory functions in the generation of T-helper cells type 1 and cytotoxic lymphocytes. Blood 1994;84:4008-27.

16 Csernok E, Ernst M, Schmitt W, Bainton DF, Gross WL. Activated neutrophils express proteinase 3 on their plasma membrane in vitro and in vivo. Clin Exp Immunol 1994:95:244-50.

17 Zhou Z, Richard C, Menard HA. De novo synthesis of proteinase 3 by cytokine primed circulating human polymorphonuclear neutrophils and mononuclear cells. J Rheumatol 2000;27:2406-11.

18 Hewins P, Williams JM, Wakelam MJ, Savage CO. Activation of Syk in neutrophils by antineutrophil cytoplasm antibodies occurs via Fcgamma receptors and CD18. J Am Soc Nephrol 2004;15:796-808.

19 Gilligan HM, Bredy B, Brady HR, Hebert MJ, Slayter HS, Xu Y, et al. Antineutrophil cytoplasmic autoantibodies interact with primary granule constituents on the surface of apoptotic neutrophils in the absence of neutrophil priming. J Exp Med 1996;184:2231-41.

20 Moosig F, Csernok E, Kumanovics G, Gross WL. Opsonization of apoptotic neutrophils by anti-neutrophil cytoplasmic antibodies (ANCA) leads to enhanced uptake by macrophages and increased release of tumour necrosis factor-alpha (TNF-alpha). Clin Exp Immunol 2000;122:499-503.

21 Noronha IL, Kruger C, Andrassy K, Ritz E, Waldherr R. In situ production of TNF-alpha, IL-1 beta and IL-2R in ANCA-positive glomerulonephritis. Kidney Int 1993;43:682-92. 
22 Komocsi A, Lamprecht P, Csernok E, Mueller A, Holl-Ulrich K, Seitzer U, et al. Peripheral blood and granuloma CD4(+)CD28(-) T cells are a major source of interferon-gamma and tumor necrosis factor-alpha in Wegener's granulomatosis. Am J Pathol 2002;160:1717-24.

23 Stone JH, Uhlfelder ML, Hellmann DB, Crook S, Bedocs NM, Hoffman GS. Etanercept combined with conventional treatment in Wegener's granulomatosis: a six-month open-label trial to evaluate safety. Arthritis Rheum 2001:44:1149-54.

24 Luqmani RA, Bacon PA, Moots RJ, Janssen BA, Pall A, Emery P, et al. Birmingham vasculitis activity score (BVAS) in systemic necrotizing vasculitis. Q J Med 1994;87:671-8.

25 Stone JH, Hoffman GS, Merkel PA, Min YI, Uhlfelder ML, Hellmann DB, et al A Disease-Specific Activity Index for Wegener's Granulomatosis: Modification of the Birmingham Vasculitis Activity Score. Arthritis Rheum 2001;44:912-20.

26 Wegener's Granulomatosis Etanercept Trial (WGET) Research Group. Etanercept plus standard therapy for Wegener's granulomatosis. N Engl J Med 2005;352:351-61.

27 Tatsis E, Reinhold-Keller E, Steindorf K, Feller AC, Gross WL. Wegener's granulomatosis associated with renal cell carcinoma. Arthritis Rheum 1999;42:751-6.

28 Knight A, Askling J, Ekbom A. Cancer incidence in a population-based cohort of patients with Wegener's granulomatosis. Int J Cancer 2002;100:82-5.

29 Pankhurst T, Savage CO, Gordon C. Malignancy is increased in ANCAassociated vasculitis. Rheumatology (Oxford) 2004;43:1532-5.

30 Tanimura Y, Kokuryo T, Tsunoda N, Yamazaki Y, Oda K, Nimura Y, et al. Tumor necrosis factor alpha promotes invasiveness of cholangiocarcinoma cells via its receptor, TNFR2. Cancer Lett 2005;219:205-13.

31 Wolfe F, Michaud K. Lymphoma in rheumatoid arthritis: the effect of methotrexate and anti-tumor necrosis factor therapy in 18,572 patients. Arthritis Rheum 2004;50:1740-51.

32 Booth AD, Jefferson HJ, Ayliffe W, Andrews PA, Jayne DR. Safety and efficacy of TNFalpha blockade in relapsing vasculitis. Ann Rheum Dis 2002;61:559.

33 Bartolucci P, Ramanoelina J, Cohen P, Mahr A, Godmer P, Le Hello C, et al. Efficacy of the anti-TNF-alpha antibody infliximab against refractory systemic vasculitides: an open pilot study on 10 patients. Rheumatology (Oxford) 2002;41:1126-32.

34 Lamprecht P, Voswinkel J, Lilienthal T, Nolle B, Heller M, Gross WL, et al. Effectiveness of TNF-alpha blockade with infliximab in refractory Wegener's granulomatosis. Rheumatology (Oxford) 2002;41:1303-7.

35 Booth A, Harper L, Hammad T, Bacon P, Griffith M, Levy J, et al. Prospective study of TNF alpha blockade with infliximab in anti-neutrophil cytoplasmic antibody-associated systemic vasculitis. J Am Soc Nephrol 2004; 15:717-21.

36 Scallon B, Cai A, Solowski N, Rosenberg A, Song XY, Shealy D, et al. Binding and functional comparisons of two types of tumor necrosis factor antagonists. J Pharmacol Exp Ther 2002;301:418-26.
37 Eriksson C, Engstrand S, Sundqvist KG, Rantapaa-Dahlqvist S. Autoantibody formation in patients with rheumatoid arthritis treated with anti-TNF alpha. Ann Rheum Dis 2005;64:403-7.

38 Charles PJ, Smeenk RJ, De Jong J, Feldmann M, Maini RN. Assessment of antibodies to double-stranded DNA induced in rheumatoid arthritis patients following treatment with infliximab, a monoclonal antibody to tumor necrosis factor alpha: findings in open-label and randomized placebo-controlled trials. Arthritis Rheum 2000;43:2383-90.

39 Carlson E, Rothfield N. Etanercept-induced lupus-like syndrome in a patient with rheumatoid arthritis. Arthritis Rheum 2003;48:1165-6.

40 Misery L, Perrot JL, Gentil-Perret A, et al. Dermatological complications of etanercept therapy for rheumatoid arthritis. Br J Dermatol 2002;146:334-5.

41 Shakoor N, Michalska M, Harris CA, Block JA. Drug-induced systemic lupus erythematosus associated with etanercept therapy. Lancet 2002;359:579-80.

42 Vermeire S, Noman M, Van Assche G, Baert F, Van Steen K, Esters N, et al. Autoimmunity associated with anti-tumor necrosis factor alpha treatment in Crohn's disease: a prospective cohort study. Gastroenterology 2003;125:32-9.

43 Jarrett SJ, Cunnane G, Conaghan PG, Bingham SJ, Buch MH, Quinn MA, et al. Anti-tumor necrosis factor-alpha therapy-induced vasculitis: case series. $J$ Rheumatol 2003;30:2287-91.

44 McCain ME, Quinet RJ, Davis WE. Etanercept and infliximab associated with cutaneous vasculitis. Rheumatology (Oxford) 2002:41:116-17.

45 Stokes MB, Foster K, Markowitz GS, Ebrahimi F, Hines W, Kaufman D, et al. Development of glomerulonephritis during anti-TNF-\{alpha\} therapy for rheumatoid arthritis. Nephrol Dial Transplant 2005;20:400-6 [Epub ahead of print 19 April 2005].

46 Doulton TW, Tucker B, Reardon J, Velasco N. Antineutrophil cyłoplasmic antibody-associated necrotizing crescentic glomerulonephritis in a patient receiving treatment with etanercept for severe rheumatoid arthritis. Clin Nephrol 2004;62:234-8.

47 Via CS, Shustov A, Rus V, Lang T, Nguyen P, Finkelman FD. In vivo neutralization of TNF-alpha promotes humoral autoimmunity by preventing the induction of CTL. J Immunol 2001;167:6821-6.

48 Bingham SJ, Buch MH, Kerr MA, Emery P, Valadao Barcelos AT. Induction of antinuclear antibodies in patients with rheumatoid arthritis treated with infliximab and leflunomide. Arthritis Rheum 2004:50:4072-3.

49 Aderka D, Wysenbeek A, Engelmann H, Cope AP, Brennan F, Molad Y, et al. Correlation between serum levels of soluble tumor necrosis factor receptor and disease activity in systemic lupus erythematosus. Arthritis Rheum 1993;36:1111-20

50 Roux-Lombard P, Lin HC, Peter JB, Dayer JM. Elevated serum levels of TNF soluble receptors in patients with positive anti-neutrophil cytoplasmic antibodies. Br J Rheumatol 1994;33:428-31.

51 Bacon PA. The spectrum of Wegener's granulomatosis and disease relapse. N Engl J Med 2005;352:330-2.

52 Luqmani RA, Bacon PA, Beaman M, Scott DG, Emery P, Lee SJ, et al. Classical versus non-renal Wegener's granulomatosis. Q J Med 1994;87:161-7. 